\title{
Buddha Image described as "King Udayana Image"
}

\section{Tamami Hamada}

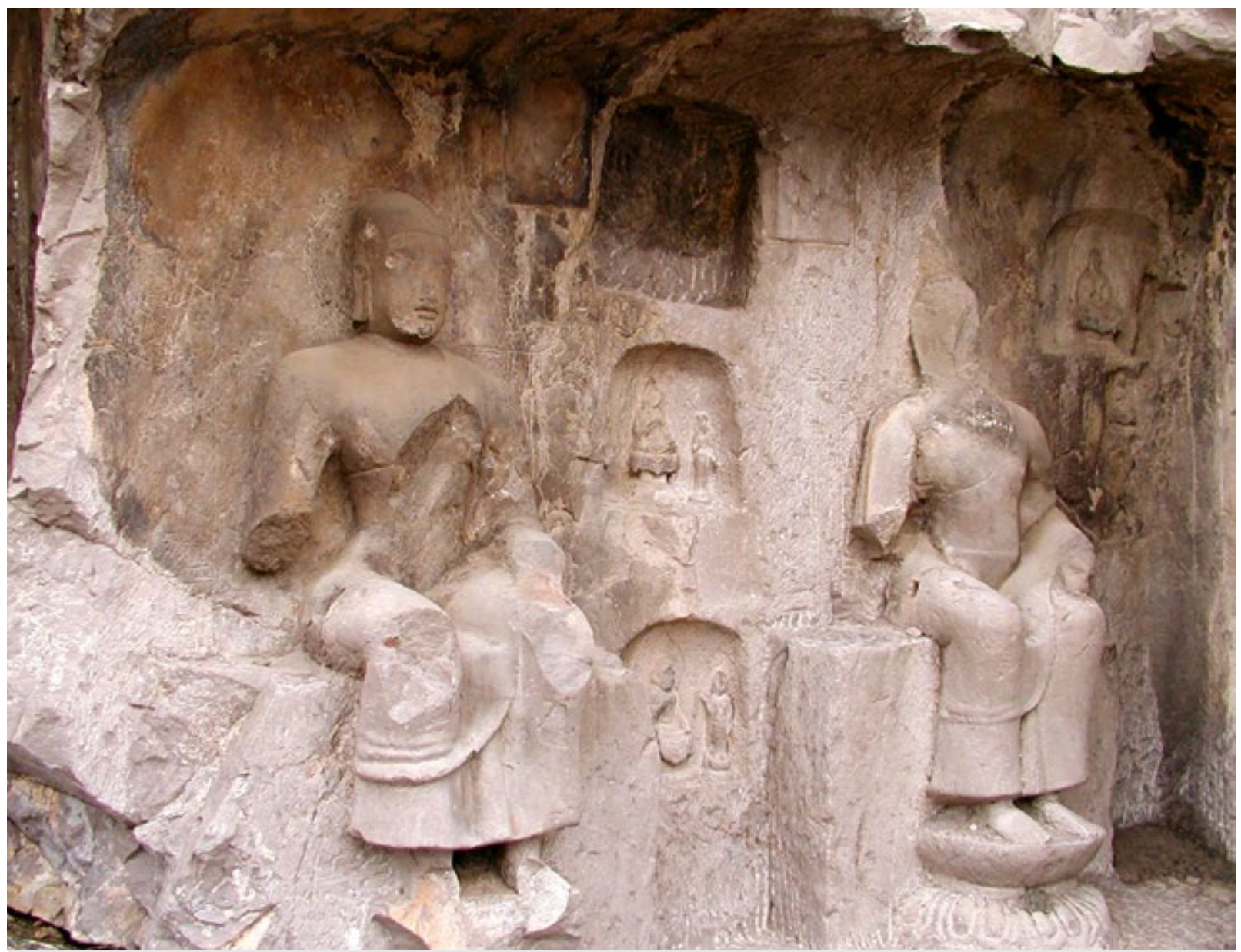

Buddha Image described as "King Udayana Image," 655 CE

This image of the Buddha (on the left, facing the viewer) belongs to Cave No. 306 of the Longmen Grottoes. The votive inscription remaining in the niche states that "a monk created this 'King Udayana Image' on October fifteenth in the sixth year of the Yonghui period (655 CE).” The style of this Buddha image displays strong Indian influence, with a low tuft on the crown of the head, wearing a thin robe, baring the right shoulder, and emphasizing the slim waistline-altogether distinctly different from the contemporary Chinese style. A nearly identical figure sits next to it. This form is replicated in over 70 statues remaining at Longmen. The votive inscriptions of the statues inform us that they were given the specific title "King Udayana Image," and not considered as a general Tathāgata image, such as the Buddha Sakyamuni. The inscriptions demonstrate that the images were created during the short period of the few decades encapsulating the reign of Tang Emperor Gaozong and Empress Wu Zetian (latter half of the seventh century). During the same period, Udayana Images were created in significant numbers not only in Longmen, but in other grottoes neighboring Luoyang, such as Gongxian. 
Due to the prominence of Indian influence in their style, some have associated the King Udayana Buddhas with the Buddhist images by the same name reportedly brought back from India to China by the monk Xuanzang. Strangely, no traces of the images remain in Chang'an where Xuanzang's images would have exercised most impact. How then can we explain their prominence in Luoyang?

According to legend, the original Udayana Image was a statue of the Buddha Sakyamuni, commissioned in India by King Udayana of Kauśāmbī. The legend explains that the statue was carved out of sandalwood while the Buddha was still alive. The king grieved the Buddha's absence while the Buddha ascended to the Heaven of Thirty-three Gods in order to preach law to his mother, Maya, and wished for a replacement. The Udayana images were understood to be both very first image of Buddha and an image carved from life. As such they were worshipped in China and Japan long after the carving of their prototype.

The legend regarding the introduction of Buddhism to China relates how the Eastern Han emperor Ming-di dreamt of a golden figure and, inspired by his dream, sent emissaries to India in search of Buddhist teachings. He had them bring back sutras and Buddhist images. By the latter half of seventh century, the legend had evolved to claim that the first image of the Buddha brought back to China by order of Emperor Ming-di wasan Udayana Image. This evolution of the legend may be linked to the fierce debates that took place between the Buddhists and the Daoists during this period. While the Tang dynasty had originally established Daoism as the primary faith (due to the fact that the imperial house shares the surname "Li" with Laozi, the founder of Daoism), Empress Wu relinquished this tradition and supported Buddhism. Moreover, the Buddhists themselves needed to promote their own religious legitimacy. The claim that the first Buddhist image brought into China was in fact the Udayana image likely developed as a way of affirming the legitimacy of the transmission of Buddhism from India to China. Additionally, at this time Empress Wu and her allies were striving to establish the new dynasty, Zhou, with their capital at the "holy city" of Luoyang, replacing the former capital of Chang'an. Han emperor Ming-di had the first Buddhist image in China brought to Luoyang, not Chang'an. The Udayana Images may have been created in Luoyang with the intent of promoting both the notion that Buddhism had been introduced to China by this route, and that at Luoyang its religious heritage was properly preserved and maintained.

Niches featuring the Udayana image are often accompanied by the imagery of a thousand Buddhas. This combination also indicates the intent to emphasize the legitimacy of Buddhist heritage passed on from one Buddha to another, and how it was perpetuated in Luoyang.

* For more information, see: Hamada, Tamami. "On the Udayana King Images in the Vicinity of Early Tang Luoyang.” Ars Buddhica vol.287 (2006).

(C) Tamami Hamada 


\section{Citation Guide}

1. Tamami Hamada, "Buddha Image described as 'King Udayana Image,"' Object Narrative, in Conversations: An Online Journal of the Center for the Study of Material and Visual Cultures of Religion (2014), doi:10.22332/con.obj.2014.6

Hamada, Tamami. "Buddha Image described as 'King Udayana Image."' Object

Narrative. In Conversations: An Online Journal of the Center for the Study of Material and Visual Cultures of Religion (2014). doi:10.22332/con.obj.2014.6

\section{Notes}

1. For more information, see: Hamada Tamami, "On the Udayana King Images in the Vicinity of Early Tang Luoyang,” Ars Buddhica 287 (2006).

\section{Yale}

Copyright 2016 Yale University All rights reserved. 
Conversations: An Online Journal of the Center for the Study of Material and Visual Cultures of Religion (mavcor.yale.edu) 